In cooperation with the Upper Eagle Regional Water Authority, Eagle River Water and Sanitation District, and the Town of Vail

\title{
Fish-Community Assessment in Gore Creek, Colorado, 1998
}

\section{-Kirby H. Wynn}

\section{Introduction}

Gore Creek drains an area of about 102 square miles, flows about 19 miles from an area along the Gore Range through the Town of Vail, and joins the Eagle River near Vail in Eagle County, Colorado (fig. 1). To properly manage water resources in the watershed, local managers are interested in a better understanding of water quality and stream biology and their relation to land uses and natural factors in the Gore Creek watershed. In response to these concerns, the Town of Vail, the Eagle River Water and Sanitation District, Vail Associates, and the Upper Eagle Regional Water Authority created the Gore Creek Watershed Management Program in 1996. The goal of this program is to provide information for the management and protection of water quality and aquatic life in the watershed.

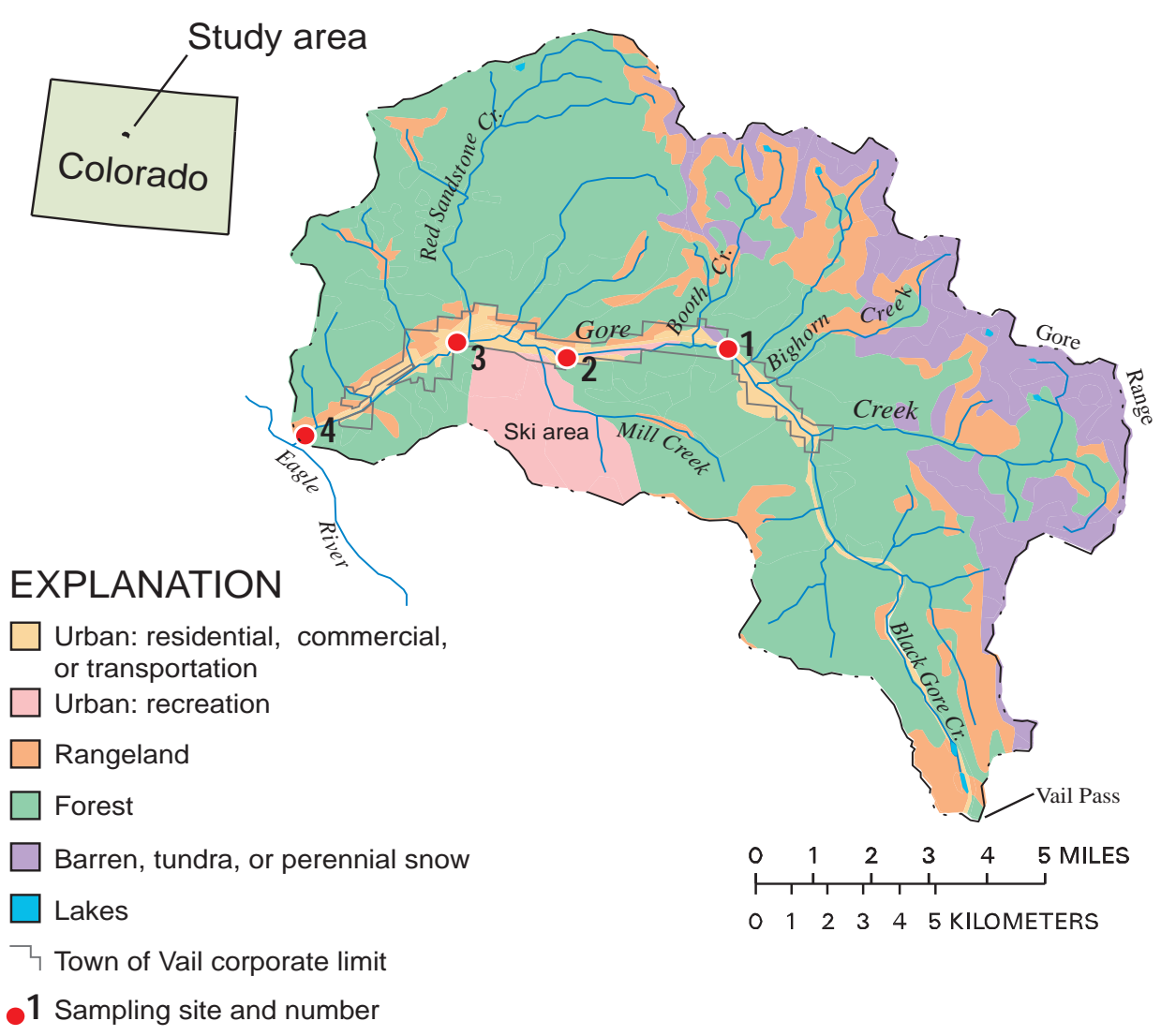

Figure 1. Fish-community sampling sites in the Gore Creek watershed.

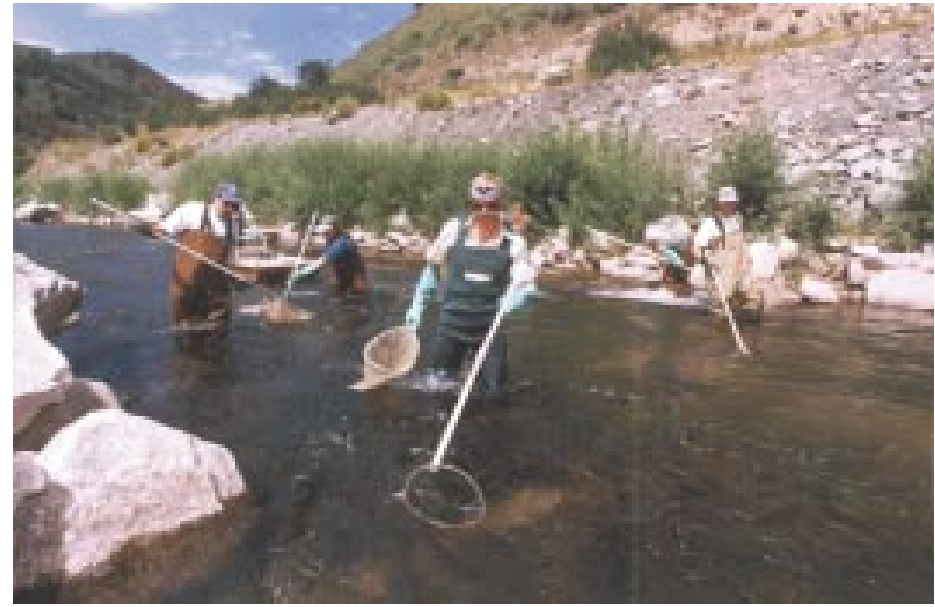

Fish-community sampling in Gore Creek. (Photograph courtesy of David Manzella.)

The lower 4-mile reach of Gore Creek, including sites 3 and 4 in figure 1, has been designated a Gold Medal trout fishery by the Colorado Division of Wildlife. The Gold Medal designation was made in recognition of the exceptional recreational value of the brown trout community in that stream reach (Weaver and Jones, 1995). The U.S. Geological Survey (USGS), in cooperation with the Town of Vail, the Eagle River Water and Sanitation District, and the Upper Eagle Regional Water Authority, collected fish-community data in four representative stream reaches along the main stem of Gore Creek in August 1998. This report describes the condition and structure of the Gore Creek fish community at four sites and relates those results to predominant water-quality indicators including instream habitat, water chemistry, and benthic algae and macroinvertebrate (aquatic organism) community characteristics.

The Gore Creek watershed has undergone significant land-use changes since the 1960s as the Vail area shifted from traditional mountain ranchlands to a four-season resort 
community. Land use/land cover in the Gore Creek watershed is 8 percent urban, 63 percent forested land, 14 percent rangeland, 14 percent barren, tundra, or perennial snow, and 1 percent other land-use/land-cover classifications (fig. 1). Although only 8 percent of the watershed is covered by urban land uses, nearly all of the development has occurred in close proximity to Gore Creek and its tributaries, causing concern that runoff from developed areas may affect water quality or stream biology.

\section{Data Collection}

Fish-community samples were collected at four sites during August 19-20, 1998. The sites were selected to identify any effects that urban and recreational land use may have on the fish community. Sites 1 through 4, in downstream order, represent stream segments that integrate the effects of increasing amounts of urban and recreational land uses. The fish-collection protocol followed for this study is described in Meador and others (1993). The sites were sampled using a towed barge direct-current electrofishing unit operated by personnel from the U.S. Fish and Wildlife Service. The length of each sampling reach was about 500 feet, and each included three types of geomorphic units (pool, riffle, and run). In order to ensure a reasonable approximation of the fish population using a similar amount of sampling effort among sites, fish were collected from each sampling reach using two complete passes with the electrofishing unit. Fish have not been stocked in Gore Creek (Tom Kingsley, Colorado Division of Wildlife, written commun., 1999); therefore, the fishcommunity data should accurately represent the community structure of Gore Creek. However, the fish community at site 4, which is located about 300 feet upstream from the confluence of the Eagle River, may be influenced by fish migrating upstream from the Eagle River, which has been stocked with rainbow and cutthroat trout several times in the 1990s. To minimize the influ-

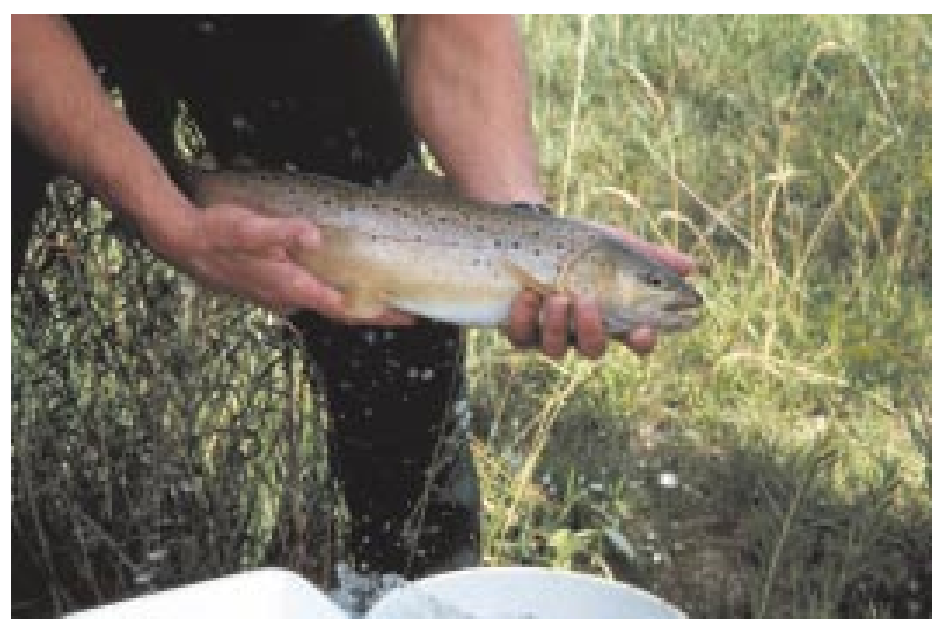

Brown trout commonly found in Rocky Mountain streams.

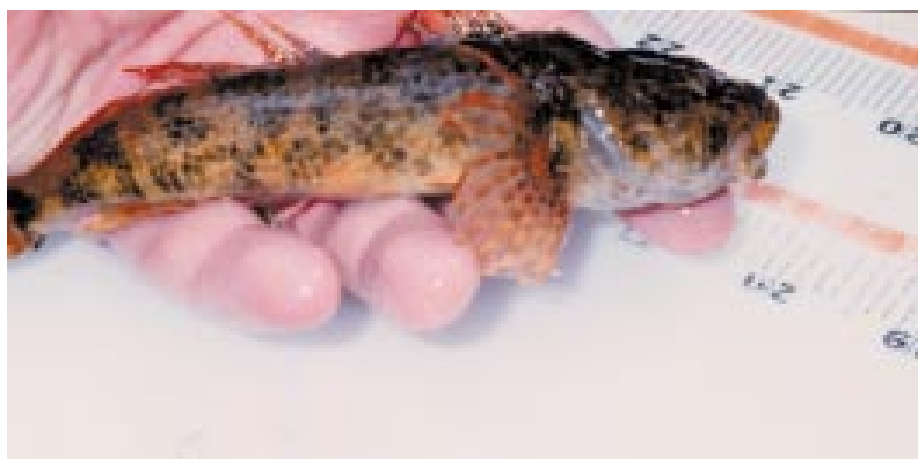

Mottled sculpin, a fish native to the Upper Colorado River Basin.

ence of habitat as a primary factor in observed fish-community differences, the selected sampling sites all contained similar, favorable instream and riparian habitat. Although site 4 was somewhat channelized and contained less riparian vegetation than the other sites, instream habitat conditions were comparable among sites. The habitat for each site was qualitatively evaluated onsite for available fish cover, streamflow and channel characteristics, bank stability, and riparian vegetation. Water temperature was measured by using a digital temperature meter. Discharge was estimated for each site from USGS streamflow-gagingstation records.

Available information from previous studies describing water quality (nutrients, specific conductance, and dissolved oxygen) and spatial distribution of benthic algae and macroinvertebrates at the same sampling sites was compiled from Wynn and others (1999) and Wynn and Spahr (1998). The data-collection protocols for those data are described in each respective report. The algae and macroinvertebrate data were collected in September 1997 and are thought to be representative of the low-flow stream conditions that existed during the fish-community assessment.

\section{Factors that Affect Fish}

The species, abundance, and condition of fish present in a stream are strongly influenced by environmental and waterquality factors including available habitat, land-surface elevation, streamflow, water temperature, dissolved-oxygen content, and specific conductance (a measure of the dissolved mineral content of water). Fish communities typical of streams in the Southern Rocky Mountains physiographic province require adequate habitat, perennial streamflow, and favorable water-temperature, dissolved-oxygen content, and specific-conductance conditions to grow and reproduce successfully. All sites were found to have adequate and similar instream habitat characteristics. This was an important finding because large differences in habitat can be the primary factor causing variation in fish-community structure among sites and can obscure the effects of other important factors such as water-quality conditions. 
Riparian vegetation was slightly degraded at sites 3 and 4 when compared to sites 1 and 2, and at all four sites a small degree of sedimentation was evident. Each site, however, contained ample amounts of cover in the form of cobble substrate, undercut banks, and overhanging vegetation suitable for fish typically found in streams of the Southern Rocky Mountains province. The land-surface elevation at sampling sites ranged from about 7,700 to 8,300 feet above sea level. Streamflow ranged from about 30 to 50 cubic feet per second among sites. Water temperature ranged from 46 to 60 degrees Fahrenheit among sites, increasing slightly as Gore Creek flowed through the Town of Vail. This temperature range is well below the thermal maximum of approximately 82 degrees Fahrenheit that can be tolerated by trout (Lee and Rinne, 1980). Dissolved-oxygen content was high and near saturation at all sites. Specific-conductance values generally were low in Gore Creek, with maximum values occurring at site 4, near the mouth of the creek. During the 1-year period from October 1996 through September 1997, hourly specific-conductance measurements at site 4 yielded average and maximum specific-conductance values of 284 and 460 microsiemens per centimeter, respectively, indicating the dissolved mineral content of Gore Creek is not excessive.

\section{Generally, trout were larger and more abundant at sites 3 and 4 within the Gold Medal fishery reach of Gore Creek than at sites farther upstream.}

\section{Fish Community}

A fish community is an assemblage of fish that share the same area of a stream and interact with each other. The structure of a fish community is determined by the species present, their relative abundances, their life stages and size distributions, and their distributions in space and time (Meador and others, 1993). Natural variability in fish communities can be attributed to differences in land-surface elevation, water temperature, water chemistry, food resources, and physical habitat. The abundance, condition, and species composition of fish communities can be influenced by water quality and habitat that are modified by surrounding land uses (Deacon and Mize, 1997). Fish-community data can have a high degree of variability, even when data are collected for the same site several times in one season. Therefore, the data presented in this report should be considered as more of a "snapshot" of the fish-community characteristics at sites in Gore Creek during August 1998 rather than a description of the longterm fish-community characteristics.

The fish-community structure differed among sites in Gore Creek. All sites contained abundant mottled sculpin (fig. 2). Large numbers of mottled sculpin, which are a native species in Colorado, are indicative of cold-water conditions found in the

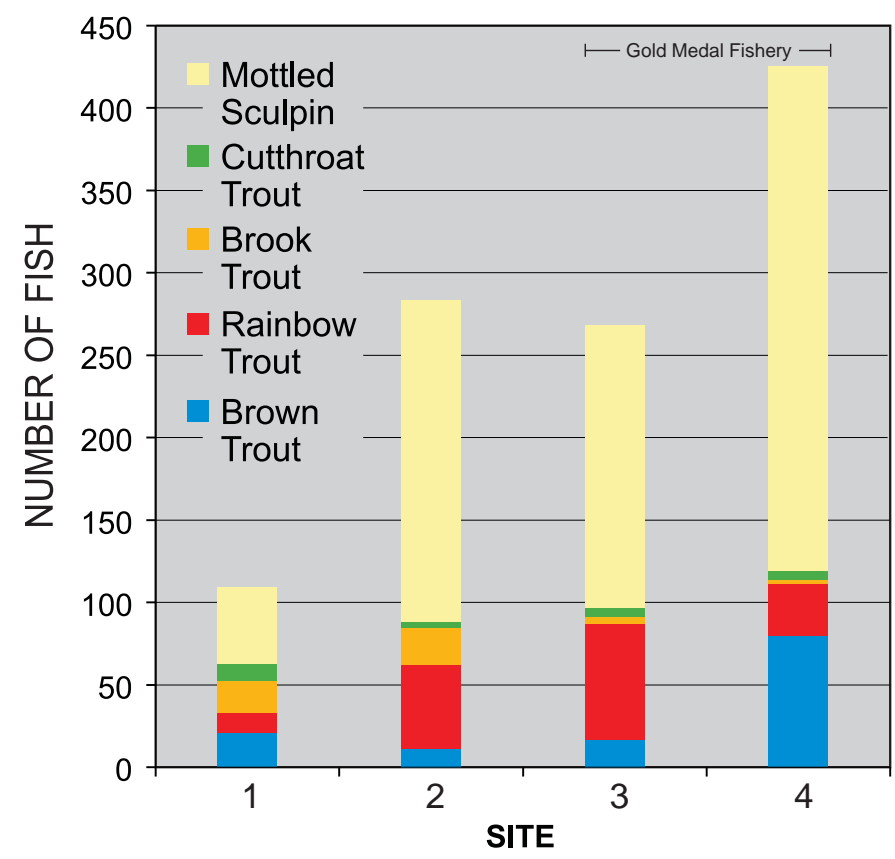

Figure 2. Fish-community structure, by site and species abundance.

Southern Rocky Mountains province (Deacon and Mize, 1997). Mottled sculpin abundance ranged from 46 fish at site 1 to 306 fish at site 4. Four trout species - cutthroat, brook, rainbow, and brown-were present at each of the four sampling sites. Total numbers of trout were similar among sites, ranging from 63 at site 1 to 119 at site 4 . The channel of Gore Creek generally becomes larger (wider and deeper) in a downstream direction. Therefore, part of the increased fish abundance at site 4 may be attributable to a slightly larger sampled surface area of the stream. Ten percent of the trout at upstream sites 1 and 2 were 12 inches or more in length; however, 25 percent of the trout were larger than 12 inches at downstream sites 3 and 4 in the Gold Medal reach of Gore Creek.

Generally, rainbow and brown trout were more abundant than cutthroat and brook trout. At site 1, all four trout species were present in relatively equal proportions, whereas the trout community was dominated by rainbow and brook trout at site 2 and rainbow and brown trout at sites 3 and 4. Brook trout are commonly associated with the more pristine headwater (higher elevation) parts of streams and were most abundant at sites 1 and 2, upstream from most of the urban land use in the Vail area.

Site 4 was unique among sites in that the brown trout community greatly outnumbered the rainbow trout community. As part of an ongoing water-quality and aquatic-ecology study of the Upper Colorado River Basin by the USGS, the fish community was assessed at site 4 during August of 1996 and 1997; brown trout dominated the trout community each year (Wynn and others, 1999). This dominance by brown trout at site 4 may be caused, in part, by brown trout migrating into Gore Creek from the Eagle 
River, where brown trout is the dominant trout species (Woodling and Chase, 1998). Also, August is within the spawning season for brown trout, thereby increasing the likelihood that some of the brown trout collected at site 4 had recently migrated into Gore Creek from the Eagle River. However, sampling of a 60 -foot reach at site 4 during April 1998 also yielded a trout community dominated by brown trout (Kirby H. Wynn, unpub. data, 1998).

Inspection of fish for anomalies such as skeletal deformities or eroded fins can give an indication of the condition of the fish community at a site. The occurrence rate for anomalies increased only slightly from about 2 percent at upstream sites 1 and 2 to about 9 percent at downstream sites 3 and 4 . This increase in anomalies at downstream sites suggests there may be more environmental stress affecting the trout at sites 3 and 4. Environmental stress could be related to a combination of factors including fishing pressure and urban development. However, the overall anomaly rate was not elevated, and determination of the causes for environmental stress on the fish community in Gore Creek was beyond the scope of this study.

\section{Relation of Fish Community to Land Use, Water Quality, and Stream Biology}

Analysis of the condition and structure of the fish community in Gore Creek is enhanced by integrating the fish data with interpretive results of additional indicators of stream quality such as nutrients, algae, and macroinvertebrates. Because these indicators are interdependent, an integrated approach can use multiple lines of evidence to develop hypotheses and support conclusions about the effects of land use on the quality of aquatic resources such as fish. Gore Creek drains larger areas of residential, commercial, transportation, and recreational urban land uses as water flows from site 1 through the Town of Vail to site 4 (fig. 1).

Benthic algae depend on adequate available resources (nutrients and sunlight) to reproduce and grow. Many types of macroinvertebrates depend on benthic algae as a microhabitat, a food source, or both. The abundance of algae-dependent macroinvertebrates may increase or decrease, depending on the abundance of their microhabitat and food resources. Because the fish in Gore Creek are insectivores, their abundance and growth rates are tied directly to the abundance and composition of the macroinvertebrate community and indirectly to the spatial distribution of nutrients and benthic algae.

The Gold Medal trout fishery appears to benefit from increased nutrients, algal biomass, and food resources associated with urban land use in the Town of Vail.
Two previous studies provided valuable insight into the relation between land use, water quality, and stream biology in Gore Creek. Wynn and others (1999) reported on the relation between land use, available nutrients (nitrogen), and the size and condition of the algae, macroinvertebrate, and fish communities at sites in Gore Creek. As part of a synoptic water-quality study in August 1996, Wynn and Spahr (1998) evaluated the change in nitrogen and phosphorus concentrations at sites in the main stem of Gore Creek. Both studies indicated that nitrogen and phosphorus concentrations are much lower at upstream sites 1 and 2 than at downstream sites 3 and 4 . The spatial distribution of nitrate nitrogen concentrations was consistent with the observed spatial distribution of algal biomass (chlorophyll- $a$, in milligrams per square meter) and macroinvertebrate-community characteristics. Algal biomass and macroinvertebrate abundance generally increased as Gore Creek flowed through increasingly urban areas between site 1 and site 4 (fig. 3). Although the increase in algal biomass was moderate from site 1 to site 4 , the macroinvertebrate abundance increased by two orders of magnitude. Much of the increased macroinvertebrate abundance consisted of pollutiontolerant midges and worms in response to moderate levels of organic enrichment and increases in nutrients and algae.

Because macroinvertebrates are the primary food supply for trout and macroinvertebrates were much more abundant at downstream sites 3 and 4, a site-to-site comparison of the relative plumpness of the trout community was done to determine if the fish communities had benefited in terms of enhanced plumpness at those sites. Relative weight, a plumpness index (Wege and Anderson, 1978; Anderson and Neumann, 1996, p. 446), was calculated for the comparisons of relative plumpness of trout among sites. Because rainbow trout were abundant at all four sites, they were the species chosen for relative plumpness comparisons among sites. Brown trout were excluded from the relative plumpness comparisons because they were most likely experiencing

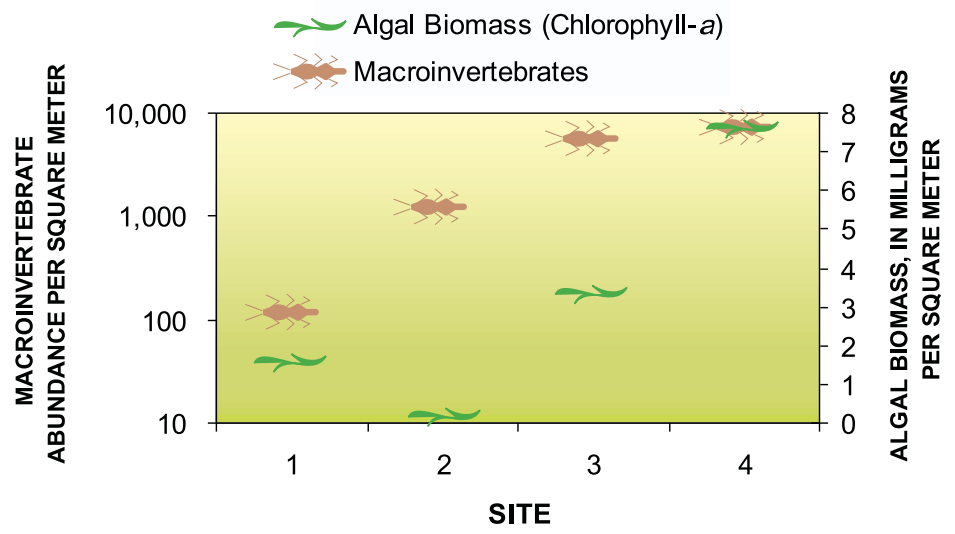

Figure 3. Macroinvertebrate abundance and algal biomass. 
temporary changes in body mass related to their annual spawning season, which coincided with the study. These temporary weight changes would have corrupted the test results.

The mean relative plumpness of rainbow trout is plotted for each site in figure 4 . Values for mean relative plumpness greater than 100 are considered to come from a fish community of above average plumpness. The mean relative plumpness values were greater than 100 at downstream sites 3 and 4 and less than 100 at upstream sites 1 and 2 . The site-to-site difference in mean relative plumpness was statistically tested using Tukey's significant difference test (Helsel and Hirsch, 1992). The mean relative plumpness of rainbow trout at site 1 was not significantly different from the other sites. However, mean relative plumpness of rainbow trout at downstream sites 3 and 4 within the Gold Medal reach was significantly (with 95-percent confidence) higher than at site 2, indicating the trout were plumper at the downstream sites. The greater plumpness of rainbow trout at the downstream sites likely was caused by increased food resources related to a combination of moderate increases in nutrients and algae and large increases in macroinvertebrate abundance.

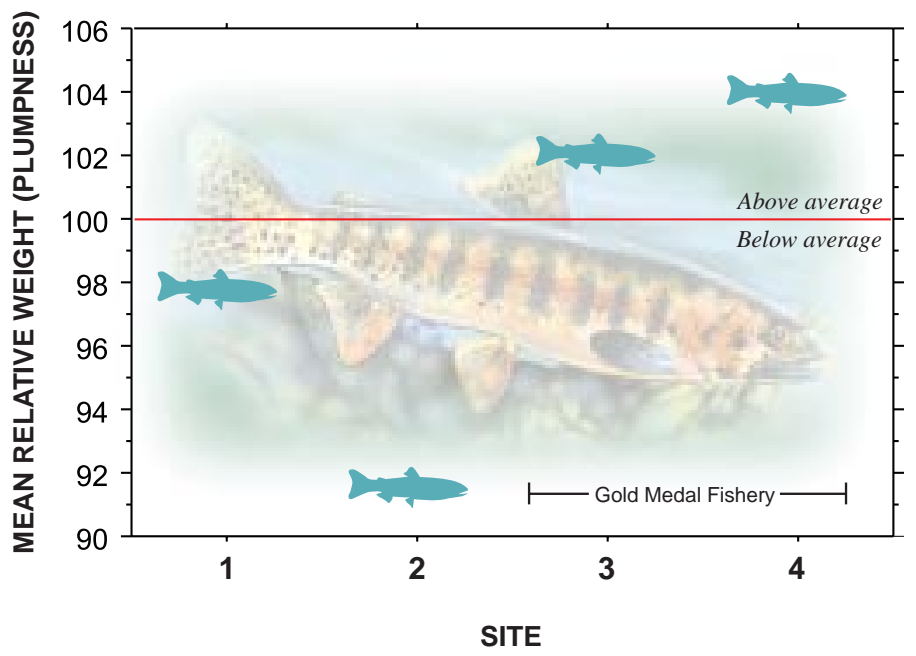

Figure 4. Mean relative weight (plumpness) of rainbow trout.

\section{Acknowledgments}

The author appreciates the assistance of the following people who made significant contributions to this fish-community assessment: Rick Krueger, U.S. Fish and Wildlife Service, provided expertise and equipment for collecting the fish-community data; Jeffrey R. Deacon, USGS, reviewed the manuscript and assisted with collection of the algae, macroinvertebrate, and fishcommunity data; and Lawrence R. DeWeese, USGS, reviewed the manuscript.

\section{References}

Anderson, R.O., and Neumann, R.M., 1996, Length, weight, and associated structural indices, in Murphy, B.R., and Willis, D.W., eds., Fisheries techniques, 2 d edition: Bethesda, Maryland, American Fisheries Society, 732 p.

Deacon, J.R., and Mize, S.V., 1997, Effects of water quality and habitat on composition of fish communities in the Upper Colorado River Basin: U.S. Geological Survey Fact Sheet 122-97, 6 p.

Helsel, D.R., and Hirsch, R.M., 1992, Statistical methods in water resources: Amsterdam, The Netherlands, Elsevier, $529 \mathrm{p}$.

Lee, R.M., and Rinne, J.N., 1980, Critical thermal maxima of five trout species in the southwestern United States: Transactions of the American Fisheries Society, v. 109, p. 632-635.

Meador, M.R., Cuffney, T.F., and Gurtz, M.E., 1993, Methods for sampling fish communities as part of the National WaterQuality Assessment Program: U.S. Geological Survey Open-File Report 93-104, 40 p.

Weaver, R.M., and Jones, J.E., 1995, Gore Creek watershed management program white paper: Wright Water Engineers, Inc., and Hydrosphere Resource Consultants, 24 p.

Wege, G.J., and Anderson, R.O., 1978, Relative weight (Wr)New index of condition for approaches to the management of small impoundment, in Novinger, G.D., and Dillard, J.G., eds., New approaches to the management of small impoundments: Bethesda, Maryland, American Fisheries Society, North Central Division, Special Publication 5, p. 79-91.

Woodling, John, and Chase, Dan, 1998, Annual biological assessment of the Eagle Mine Site superfund site, Eagle County, Colorado: Colorado Division of Wildlife, Denver, Colorado, $97 \mathrm{p}$.

Wynn, K.H., and Spahr, N.E., 1998, Low-flow water-quality characterization of the Gore Creek watershed, Upper Colorado River Basin, August 1996: U.S. Geological Survey Fact Sheet 167-97, 4 p.

Wynn, K.H., Bauch, N.J., and Driver, N.E., 1999, Gore Creek watershed, Colorado-Assessment of historical and current water quantity, water quality, and aquatic ecology, 1968-98: U.S. Geological Survey Water-Resources Investigations Report 99-4270.

U.S. Geological Survey, Water Resources Division Denver Federal Center, Bldg. 53, MS 415 Denver, CO 80225-0046

e-mail: khwynn@usgs.gov

Design: John Evans

Editing: Mary Kidd Manuscript and Layout: Alene Brogan 


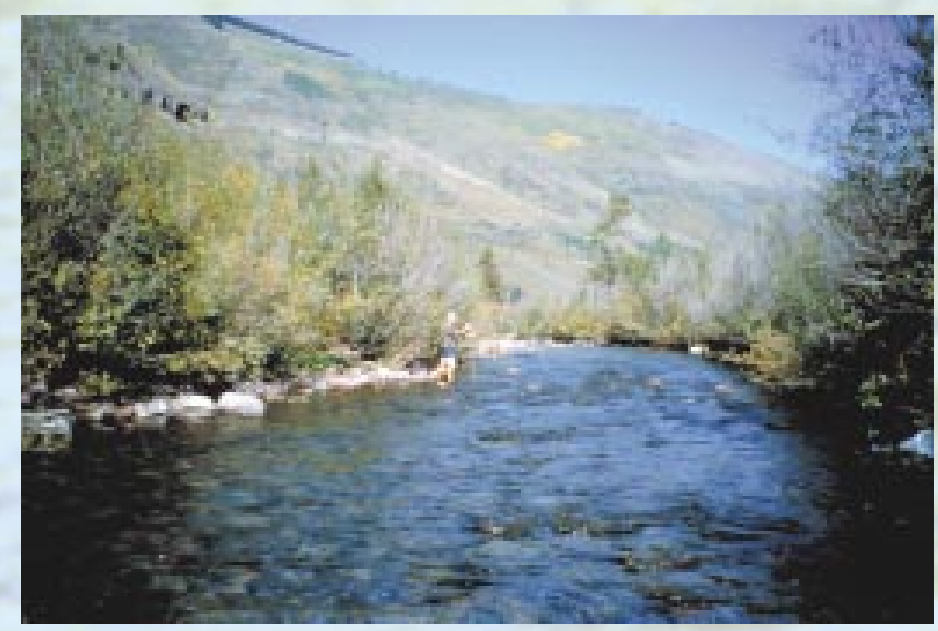

Site 1

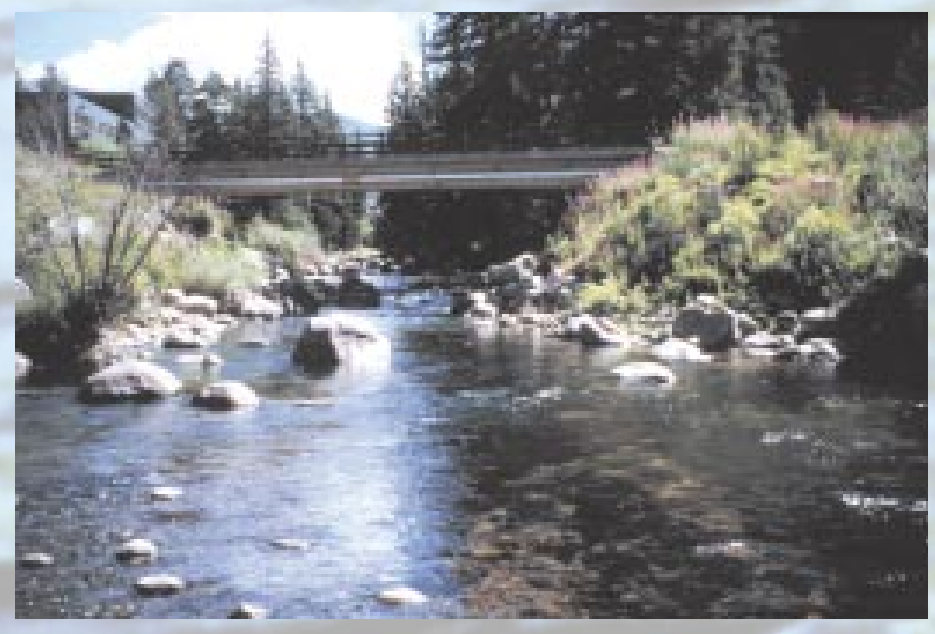

Site 3

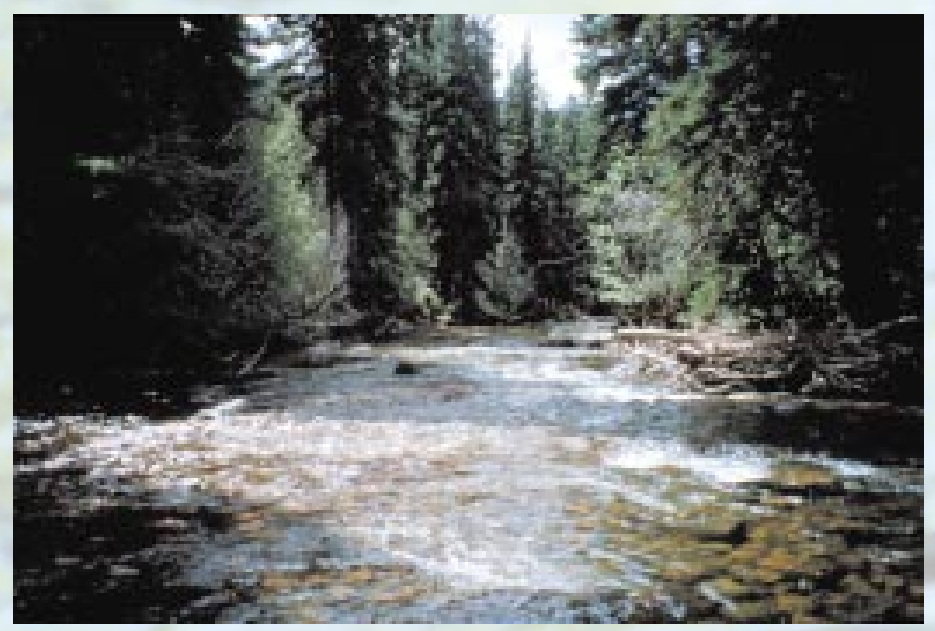

Site 2

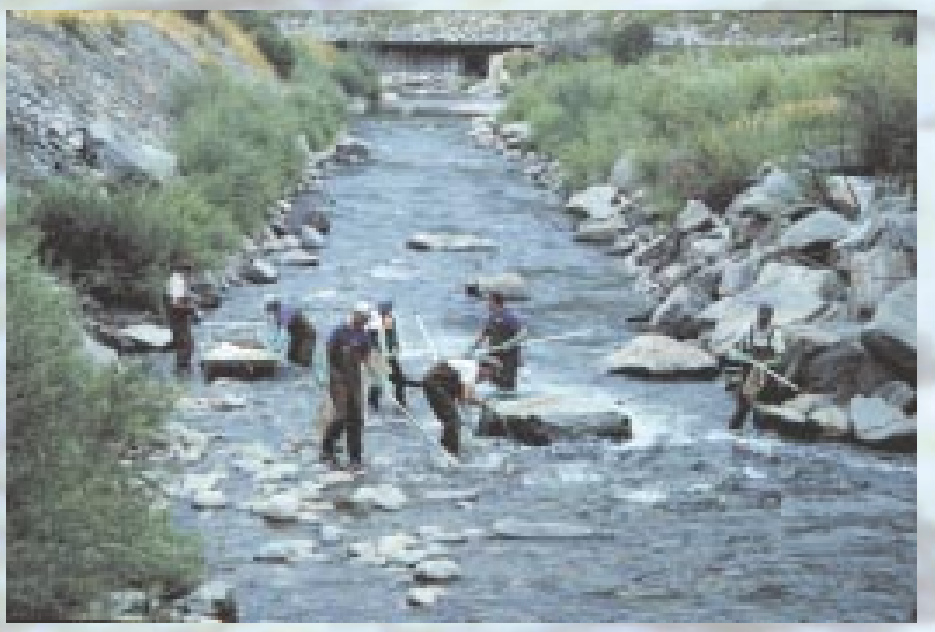

Site 4 